ISSN 2723-7583 (Online)

\title{
PENILAIAN DAYA DUKUNG KAWASAN PANTAI SIRING KEMUNING BAGI
} PERUNTUKAN EKOWISATA PANTAI

\section{Capability Assessment Coastal Region Siring Kemuning For Ecotourism Appropriation Beach}

\author{
Muhamad Reza Pahlevi* dan Agus Romadhon
}

\author{
Program Studi Ilmu Kelautan, Jurusan Kelautan dan Perikanan, Fakultas Pertanian, Universitas \\ Trunojoyo Madura
}

*Corresonden author email: muhamad.pahlevie@gmail.com

Submitted: 15 September 2020 / Revised: 12 October 2020 / Accepted: 13 October 2020

http://doi.org/10.21107/juvenil.v1i3.8555

\begin{abstract}
Bangkalan Regency is one of the districts on the island of Madura that has the potential to develop and advance from various sectors. Ecotourism is one sector that can be a mainstay of Bangkalan district. Ecotourism is an environmental and ecological preservation activity that is used as an effort by both the government and the private sector to promote an area or region as a tourist destination that will expand employment opportunities and improve the economy of local residents. Siring Kemuning Beach is one area that has the potential to become a tourist place. The purpose of this study was to determine the status of water quality, the relationship of ecosystem services, the suitability and assessment of the carrying capacity of the Siring Kemuning coastal area. The method used is the comparison between the data obtained from the results of research with established quality standards. The results of this study indicate that the Siring Kemuning beach has a status of good water quality. Status of the availability of ecosystem services for tourism development is still able to provide a number of ecosystem services. The Tourism Suitability Index (IKW) of Siring Kemuning Beach has a very appropriate and appropriate category (IKW 2.195 - 2.595). Siring Kemuning Beach has an estimated carrying capacity in station 1 at low tide 548 people / day and 68 people at tide, at station 2 at 840 people / day at low tide and 115 people / day at high tide, and station 3 at low tide at 903 people / day and 113 people / day at high tide.
\end{abstract}

Keywords: Siring Kemuning Beach, beach ecotourism, tourism suitability index, and regional carrying capacity

\begin{abstract}
ABSTRAK
Kabupaten Bangkalan merupakan salah satu kabupaten di pulau Madura yang memiliki potensi untuk berkembang dan maju dari berbagai sektor. Ekowisata merupakan salah satu sektor yang dapat menjadi andalan dari kabupaten Bangkalan. Ekowisata merupakan aktivitas pelestarian lingkungan serta ekologis yang dijadikan salah satu upaya baik pemerintah maupun swasta guna mempromosikan suatu daerah atau wilayah sebagai tujuan destinasi wisata yang akan memperluas lapangan pekerjaan serta meningkatkan perekonomian warga sekitar.Pantai Siring Kemuning merupakan salah satu kawasan yang berpotensi untuk dijadikan tempat pariwisata. Tujuan penelitian ini untuk mengetahui status mutu perairan, keterkaitan jasa ekosistem, kesesuaian dan penilaian daya dukung kawasan pantai Siring Kemuning. Metode yang digunakan yaitu dengan komparasi antara data yang di dapat dari hasil penelitian dengan baku mutu yang telah ditetapkan. Hasil dari penelitian ini menunjukkan bahwa pantai Siring Kemuning memiliki status mutu perairan yang baik. Status ketersediaan jasa ekosistem untuk pengembangan wisata masih mampu menyediakan sejumlah jasa ekosistem. Indeks Kesesuaian Wisata (IKW) Pantai Siring Kemuning memiliki kategori sangat sesuai dan sesuai (IKW 2,195 - 2,595. Pantai Siring Kemuning memiliki estimasi daya dukung kawasan pada stasiun 1 kondisi surut 548 orang/hari dan saat pasang 68 orang/hari, pada stasiun 2 sebesar 840 orang/hari saat surut dan 115 orang/hari saat pasang,dan stasiun 3 pada saat surut sebesar 903 orang/hari dan 113 orang/ hari saat pasang.
\end{abstract}

Kata Kunci : Pantai Siring Kemuning, Ekowisata pantai, Indeks Kesesuaian Wisata, dan Daya Dukung Kawasan 


\section{PENDAHULUAN}

Kabupaten Bangkalan merupakan salah satu kabupaten di Pulau Madura yang berdekatan dengan ibu kota Provinsi Jawa Timur yaitu Kota Surabaya. Bangkalan terletak pada Barat Pulau Madura dan di sebelah Utara kota Surabaya. Bangkalan memiliki potensi untuk berkembang dan maju yang sangat besar. Kemajuan serta perkembangan dapat datang dari berbagai sektor. Ekowisata merupakan salah satu sektor yang dapat menjadi andalan dari kabupaten Bangkalan (Syamsi, 2016). Ekowisata adalah aktivitas pelestarian lingkungan serta ekologis yang dijadikan salah satu upaya baik pemerintah maupun swasta guna mempromosikan suatu daerah atau wilayah sebagai tujuan destinasi wisata yang nantinya akan memperluas lapangan pekerjaan serta meningkatkan perekonomian warga sekitar (Johan, 2017). Salah satu kawasan yang berpotensi untuk dijadikan tempat pariwisata yaitu pantai Siring Kemuning (BAPPEDA Bangkalan, 2013).

Penilaian kesesuaian dan daya dukung kawasan digunakan agar dapat menentukan kualitas kepuasan serta kenyamanan wisatawan dalam menikmati kegiatan wisata pada area yang telah dikunjungi aman dari bahaya yang mengancam. Jumlah pengunjung yang telah mengunjungi objek wisata berkaitan erat dengan daya dukung kawasan objek wisata tersebut. Suatu objek wisata yang melebihi dari kapasitas daya dukung maka berdampak dengan berkurangnya kepuasan serta kenyamanan bagi wisatawan. Hal tersebut dikarenakan pengunjung wisata menginginkan pemandangan dari wisata tersebut dibandingkan melihat kepadatan wisatawan (Lucyanti et al., 2013). Berangkat dari hal tersebut penelitian ini dilakukan untuk menilai kelayakan pengembangan ekowisata dan daya dukung di Pantai Siring Kemuning.

\section{MATERI DAN METODE}

Waktu dan tempat penelitian dilaksanakan mulai bulan Januari 2020 hingga bulan Maret 2020 yang berlokasi pada Pantai Siring Kemuning Bangkalan (Gambar 1)

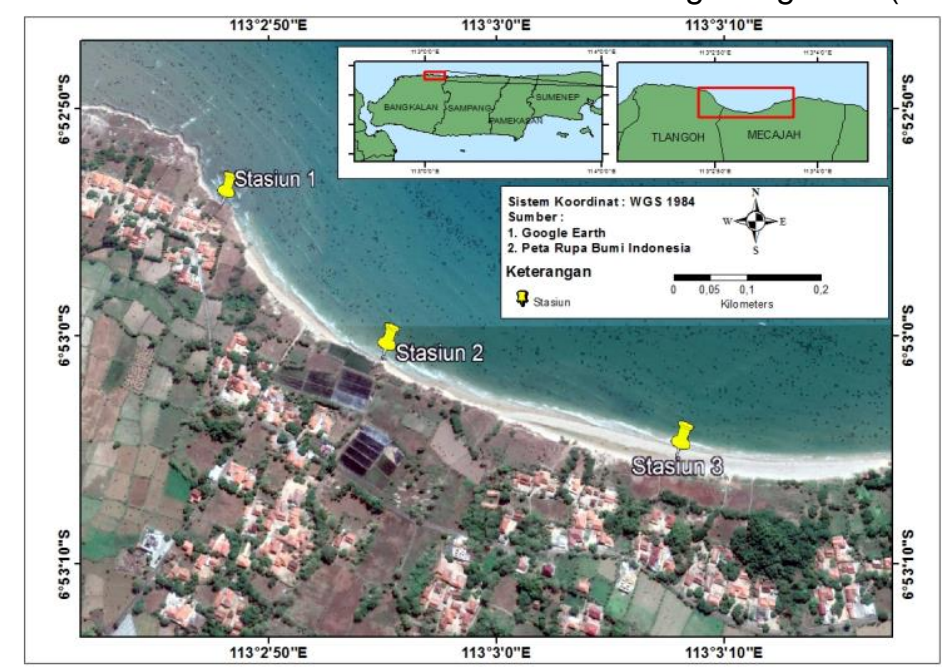

Gambar 1. Peta Lokasi Penelitian

Sumber peta Google Earth (2020)

Penelitian ini menggunakan teknik purpossive sampling untuk penentuan lokasi (Sukandar et

Tabel 1. Titik koordinat stasiun penelitian

\begin{tabular}{|c|c|}
\hline \multirow{2}{*}{ Stasiun Sampling } & Koordinat \\
\hline & LS \\
\hline Stasiun I & $113^{\circ} 2^{\prime} 47.78^{\prime \prime}$ \\
\hline Stasiun II & $113^{\circ} 2^{\prime} 55.26^{\prime \prime}$ \\
\hline Stasiun III & $113^{\circ} 3^{\prime} 7.37^{\prime \prime}$ \\
\hline Sumber Data & $\begin{array}{llll}\text { yang } & \text { dibutuhkan. } & \text { Data } & \text { Sekunder }\end{array}$ \\
\hline $\begin{array}{l}\text { Data Primer pengumpulan yang dilakukan } \\
\text { secara langsung pada lapang seperti } \\
\text { pengambilan data pH, Salinitas, DO, suhu, } \\
\text { kecerahan serta parameter pendukung lainnya }\end{array}$ & $\begin{array}{l}\text { jurnal, buku, studi ilmiah, skripsi yang } \\
\text { berkaitan dengan judul serta pembahasan } \\
\text { yang sama atau penelitian yang telah } \\
\text { dilakukan sebelum penelitian ini dilakukan. }\end{array}$ \\
\hline
\end{tabular}


Juvenil, 1(3), 310-324, (2020)

Penilaian Permintaan (Demand) Jasa
Ekosistem

Penilaian permintaan (demand) jasa ekosistem dilakukan dengan memberi nilai atas permintaan manusia untuk jasa ekosistem di jenis tutupan lahan tertentu pada skala yang meliputi:

\begin{tabular}{|c|c|c|c|}
\hline 0 & $\begin{array}{c}\text { Tidak } \\
\text { Relevansi }\end{array}$ & 2 & Relevan \\
\hline 1 & $\begin{array}{l}\text { Cukup } \\
\text { Relevan }\end{array}$ & 3 & $\begin{array}{c}\text { Sangat } \\
\text { Relevansi }\end{array}$ \\
\hline
\end{tabular}

Tabel 4. Penilaian Permintaan (Demand) Jasa Ekosistem

\begin{tabular}{|c|c|c|c|c|c|c|c|c|c|}
\hline \multirow{2}{*}{\multicolumn{2}{|c|}{$\begin{array}{c}\text { Natural Capital } \\
\text { Asset }\end{array}$}} & \multicolumn{8}{|c|}{ Jasa Ekosistem Pantai Siring Kemuning } \\
\hline & & $a$ & $b$ & c & $d$ & $\mathrm{e}$ & $f$ & $\mathrm{~g}$ & $\mathrm{~h}$ \\
\hline 1 & Kualitas & & & & & & & & \\
\hline 2 & Tekstur Pantai & & & & & & & & \\
\hline 3 & Pemukiman & & & & & & & & \\
\hline 4 & Tanah Terbuka & & & & & & & & \\
\hline 5 & Vegetasi & & & & & & & & \\
\hline 6 & Laut & & & & & & & & \\
\hline
\end{tabular}

\begin{tabular}{|l|l|}
\hline 0 & Tidak ada relevansi \\
1 & Cukup relevan \\
\hline 2 & Relevan \\
\hline 3 & Sangat relevan \\
\hline
\end{tabular}

Keterangan
a. Estetik
e. Keberlanjutan Hidup
b. Biodiversity
f. Pembelajaran
c. Budaya
g. Rekreasi
d. Ekonomi
h. Spiritual

\section{Penilaian Status Keseimbangan Jasa Ekosistem}

Penilaian status keseimbangan jasa ekosistem dapat diperoleh dengan nilai matrik suplai ekosistem dikurangi nilai matrik permintaan jasa ekosistem. Skala yang digunakan untuk

penilaian status keseimbangan yaiitu dari -3 hingga 3 . Tanda (-) menunjukkan permintaan yang melebihi pasokan, 0 menunjukkan keseimbangan, dan tanda $(+)$ menunjukkan pasokan melebihi permintaan. Penilaian status keseimbangan jasa ekosistem dapat dilihat pada Tabel 5.

Tabel 5. Penilaian Status Keseimbangan Jasa Ekosistem Pantai

\begin{tabular}{|c|c|c|c|c|c|c|c|c|c|}
\hline \multirow{2}{*}{\multicolumn{2}{|c|}{$\begin{array}{c}\text { Natural Capital } \\
\text { Asset }\end{array}$}} & \multicolumn{8}{|c|}{ Jasa Ekosistem Pantai Siring Kemuning } \\
\hline & & $\mathrm{a}$ & $\mathrm{b}$ & C & d & e & $f$ & $g$ & $\mathrm{~h}$ \\
\hline 1 & Kualitas & & & & & & & & \\
\hline 1 & Perairan & & & & & & & & \\
\hline 2 & Tekstur Pantai & & & & & & & & \\
\hline 3 & Pemukiman & & & & & & & & \\
\hline 4 & Tanah Terbuka & & & & & & & & \\
\hline 5 & Vegetasi & & & & & & & & \\
\hline 6 & Laut & & & & & & & & \\
\hline
\end{tabular}

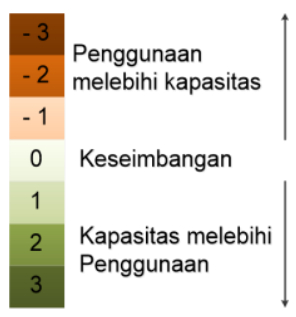

Keterangan
a. Estetik
e. Keberlanjutan Hidup
b. Biodiversity
c. Budaya
f. Pembelajaran
d. Ekonomi
g. Rekreasi
h. Spiritual

\section{Kesesuaian Wisata Pantai}

Indeks Kesesuaian Wisata (IKW) merupakan indeks yang digunakan sebagai analisa kesesuaian wisata pantai. Menurut Yulianda (2019) indeks kesesuaian wisata dapat di kategorikan pada matriks kesesuaian, matriks kesesuaian wisata dapat dilihat pada Tabel 6 .

Tabel 6. Kesesuaian Wisata Bahari Kategori Ekowisata Pantai

\begin{tabular}{ccccc}
\hline No & Parameter & Bobot & Kategori & Skor \\
\hline & & Pasir Putih & 3 \\
1 & Tipe Pantai & 0,200 & Pasir putih campur pecahan karang & 2 \\
& & Pasir hitam, sedikit terjal & 1 \\
& & Lumpur, berbatu, terjal & 0 \\
2 & Lebar Pantai $(\mathrm{m})$ & 0,200 & $>15$ & 3 \\
& & $10-15$ & 2 \\
\hline
\end{tabular}




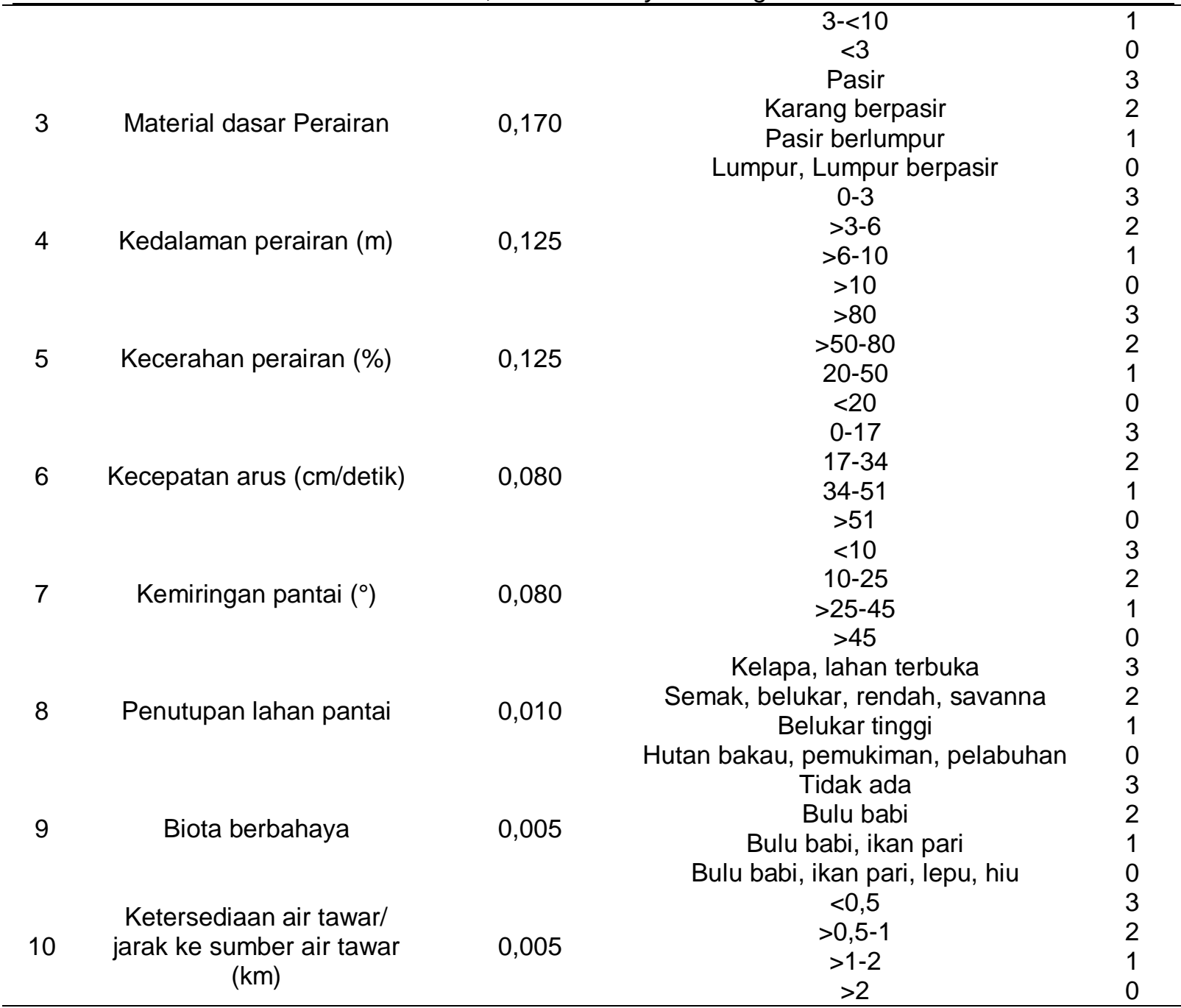

Sumber : (Yulianda, 2019)

Indeks Kesesuaian wisata menurut Yulianda, (2019) rumus yang digunakan untuk analisa kesesuaian wisata pantai yaitu:

Keterangan

$$
\mathrm{IKW}=\sum_{\mathrm{i}=1}^{\mathrm{n}}(\mathrm{Bi} \times \mathrm{Si})
$$

$$
\begin{array}{ll}
\text { IKW } & : \text { Indeks Kesesuaian Wisata } \\
\mathrm{n} & : \text { Banyaknya parameter kesesuaian } \\
\mathrm{Bi} & : \text { Bobot parameter ke-i } \\
\mathrm{Si} & : \text { Skor parameter ke-i }
\end{array}
$$

Kategori Nilai IKW sebagai berikut

Kategori IKW : IKW $\geq 2,5$

$$
\begin{aligned}
& 2,0 \leq \mathrm{IKW}<2,5 \\
& 1 \leq \mathrm{IKW}<2,0 \\
& \mathrm{IKW}<1
\end{aligned}
$$

\section{Analisa Daya Dukung Kawasan}

Penilaian daya dukung kawasan dilakukan guna mengelola aktivitas suatu sumberdaya alam dan lingkungan agar tidak melebihi daya tampung wisatawan yang datang pada kawasan wisata, maka dari itu penilaian daya dukung kawasan (DDK) sangat penting untuk

dilakukan. Menurut Yulianda, (2019) penilaian DDK dapat dilakukan dengan menggunakan rumus:

Keterangan

$$
\mathrm{DDK}=\mathrm{K} \times \frac{\mathrm{Lp}}{\mathrm{Lt}} \times \frac{\mathrm{Wt}}{\mathrm{WP}}
$$

DDK : Daya Dukung Kawasan

K : Potensi Ekologis Pengunjung per satuan area (Manusia)

Lp : Luas wilayah $\left(\mathrm{m}^{2}\right)$ atau panjang wilayah $(\mathrm{m})$ yang dapat digunakan

Sangat St sesuai: Bagian area sebagai golongan tertentu ( $\mathrm{m}^{2}$ atau $\left.\mathrm{m}\right)$

Sesuai $W_{t}$ : Waktu yang disediakan sebagai Tidak sesuai aktivitas dalam satu hari (jam) Sangat tidak sẹsuaktivitas dalam satu hari (jam) untuk setiap aktivitas (jam)

Setiap aktivitas yang dapat dilakukan pada tempat ekowisata pantai ditampilkan dalam form potensi ekologis berdasarkan kegiatan pengunjung dapat dilihat pada Tabel 7 . 
Juvenil, 1(3), 310-324, (2020)

Tabel 7. Form Potensi Ekologis Pengunjung dan Luas Area Pemanfaatan

\begin{tabular}{|c|c|}
\hline $\begin{array}{c}\text { Jenis } \\
\text { Kegiatan }\end{array}$ & $\begin{array}{c}\mathrm{K} \\
\text { ( } \sum \text { pengunjung) }\end{array}$ \\
\hline $\begin{array}{l}\text { Rekreasi } \\
\text { Pantai }\end{array}$ & $25 \mathrm{~m}$ \\
\hline $\begin{array}{l}\text { HASIL } \\
\text { Status Mutu } \\
\text { Kemuning }\end{array}$ & $\begin{array}{l}\text { DAN PEMBAHASAN } \\
\text { Perairan Di Pantai Siring }\end{array}$ \\
\hline $\begin{array}{l}\text { Penentuan sta } \\
\text { pantai didasark } \\
\text { perairan yang } \\
\text { Pengukuran st } \\
\text { bertujuan ur } \\
\text { lingkungan ters } \\
\text { dijadikan sebag } \\
\text { Adapun hasil } \\
\text { perairan yang } \\
\text { Kemuning, Bar } \\
\text { dilihat pada dat }\end{array}$ & $\begin{array}{l}\text { tus mutu perairan dari suatu } \\
\text { kan pada kondisi lingkungan } \\
\text { terdapat pada lokasi tersebut. } \\
\text { tatus mutu perairan tersebut } \\
\text { ntuk mengetahui kondis } \\
\text { ebut layak atau tidaknya untuk } \\
\text { gai kawasan ekowisata pantai. } \\
\text { dari pengukuran status mutu } \\
\text { ada pada pantai Siring } \\
\text { ngkalan yang dilakukan dapat } \\
\text { a sebagai berikut: }\end{array}$ \\
\hline
\end{tabular}

\section{Salinitas}

Berdasarkan hasil yang telah diukur pada saat lapang telah diketahui kadar salinitas di ketiga stasiun dengan titik berbeda yang diukur ketika waktu pasang dan surut berada di kategori sesuai, dengan kadar salinitas ketika waktu pasang rata-rata sebesar 35,3-35,6 ppt dan ketika surut rata-rata sebesar 34,3-35 ppt. Hasil pengukuran salinitas tersebut sesuai dengan penelitian dari (Telaumbanua et al, 2017) yang mengatakan nilai salinitas di wilayah pesisir Kabupaten Nias Utara berada pada kisaran 33-34 ppt. Menurut (Telaumbanua et al., 2017) kisaran salinitas tersebut memungkinkan terumbu karang hidup dengan kondisi baik sehingga dapat menjadikan daya tarik tersendiri untuk wisata snorkeling dan diving.

\section{Suhu}

Berdasarkan hasil dari pengukuran saat lapang telah diketahui bahwasannya suhu di ketiga stasiun yang telah diukur ketika pasang dan surut dalam kategori sesuai, dengan ratarata nilai suhu pasang $29^{\circ} \mathrm{C}-29,7^{\circ} \mathrm{C}$ dan ratarata nilai suhu surut $28,8^{\circ} \mathrm{C}-30,6^{\circ} \mathrm{C}$. Hal tersebut sesuai dengan penelitian dari (Tambunan et al., 2013) yang mengatakan bahwa suhu di perairan pantai Tanjung Pesona nilai suhu berkisar $29,2-30,15^{\circ} \mathrm{C}$. Selain itu nilai suhu tersebut sesuai dengan penelitian (Ermawan, 2008) dengan kondisi perairan di pesisir pantai Prigi $23-29^{\circ} \mathrm{C}$. 
telah diukur berada di kategori sesuai, dengan nilai ketika surut $0,2 \mathrm{~m} / \mathrm{s}$ dan ketika $0,21 \mathrm{~m} / \mathrm{s}$. Hal tersebut sesuai dengan penelitian dari (Dewi et al., 2018) kecepatan arus pada perairan Selat Asam di stasiun 1 sebesar $0,03 \mathrm{~m} / \mathrm{s}$, stasiun II sebesar $0,1 \mathrm{~m} / \mathrm{s}$ dan stasiun III sebesar $0,1 \mathrm{~m} / \mathrm{s}$. Menurut (Sari dan Usman) kecepatan arus pada lokasi penelitian ini masuk ke dalam kategori arus lambat dengan nilai $0-0,25 \mathrm{~m} / \mathrm{s}$. Menurut (Yulisa et al., 2016) keamanan wisata dalam berenang berkaitan dengan kecepatan arus. Arus yang kuat sangat berbahaya untuk wisatawan sedangkan arus yang lemah sangat baik untuk wisatawan melakukan kegiatan berenang atau mandi di pantai.

\section{Kecerahan Perairan}

Berdasarkan hasil pengukuran saat dilapang telah diketahui bahwa kecerahan perairan yang telah diukur berada di kategori tidak sesuai dengan baku mutu. Kecerahan di ketiga stasiun yang diukur pada saat pasang maupun surut masih dibawah baku mutu yaitu kurang dari $80 \%$ yang dimana nilai rata-rata saat surut $61,1 \%-62 \%$ dan nilai rata-rata saat pasang 56,1\% - 59,4 \%. Menurut (Akhmad dan Koesoemadji, 2014) perairan dengan kecerahan $60 \%$ disebabkan terjadinya pengadukan substrat tersuspensi yang mempengaruhi kecerahan karena pada saat pengambilan data kecerahan terjadi di musim penghujan. Hal tersebut sesuai dengan waktu pengambilan di musim penghujan awal bulan Januari. Kecerahan perairan menurut (Ramadhan et al., 2014) merupakan parameter yang mencirikan nilai keindahan

Tabel 8. Suplai jasa ekosistem di pantai Siring Kemuning

\begin{tabular}{|c|c|c|c|c|c|c|c|c|c|}
\hline \multirow{2}{*}{\multicolumn{2}{|c|}{$\begin{array}{c}\text { Natural Capital } \\
\text { Asset }\end{array}$}} & \multicolumn{8}{|c|}{ Jasa Ekosistem Pantai Siring Kemuning } \\
\hline & & a & $\mathrm{b}$ & C & d & e & $f$ & $\mathrm{G}$ & $\mathrm{h}$ \\
\hline 1 & $\begin{array}{l}\text { Kualitas } \\
\text { Perairan }\end{array}$ & 3 & 3 & 0 & 2 & 2 & 0 & 3 & 0 \\
\hline 2 & Tekstur Pantai & 3 & 2 & 0 & 2 & 2 & 1 & 3 & 0 \\
\hline 3 & Pemukiman & 0 & 0 & 1 & 0 & 0 & 1 & 0 & 0 \\
\hline 4 & Tanah Terbuka & 1 & 1 & 0 & 0 & 0 & 0 & 1 & 0 \\
\hline 5 & Vegetasi & 1 & 1 & 0 & 1 & 1 & 1 & 1 & 0 \\
\hline 6 & Laut & 3 & 3 & 2 & 3 & 3 & 3 & 3 & 3 \\
\hline
\end{tabular}

\section{Keterangan}
a. Estetik
b. Biodiversity
c. Budaya
e. Keberlanjutan Hidup
d. Ekonomi
f. Pembelajaran
g. Rekreasi

Jasa ekosistem merupakan proses ekologi serta mekanisme yang membuat kondisi yang mempertahankan dan memenuhi kehidupan manusia. Jasa ekosistem pantai dalam pemanfaatannya harus seimbang dengan upaya pemeliharaan dan kelestariannya sehingga tercipta pemanfaatan yang terbaik pemandangan saat melakukan kegiatan wisata dan kecerahan perairan yang keruh akan mengurangi estetika keindahan berwisata di pantai dan terkesan kotor.

\section{Analisis Socio Ecological System (SES)}

Analisis socio ecological system (SES) merupakan konsep yang luas tentang manusia dialam yang dimana sistem manusia serta sistem ekologi dipandang sebagai bagian yang terkait erat (Romadhon, 2013). Pengambilan data dilakukan dengan wawancara secara tidak terstruktur. Wawancara tidak terstruktur merupakan wawancara bebas yang dimana peneliti tidak menggunakan pedoman wawancara yang sistematis dan lengkap dalam pengambilan datanya (Ernata, 2017). Adapun hasil analisis sosio ecological system (SES) yang dilakukan antara lain :

\section{Suplai Jasa Ekosistem}

Suplai jasa ekosistem mengacu pada penyedia dari wilayah tertentu terhadap barang dan jasa ekosistem dalam jangka waktu tertentu (Romadhon, 2013). Hasil penilaian terhadap suplai jasa ekosistem yang ada di pantai Siring Kemuning didapat dengan melalui wawancara warga setempat dengan menanyakan Natural Capital Asset berhubungan dengan estetik, biodiversitas, budaya, ekonomi, keberlanjutan hidup, pembelajaran, rekreasi, dan spiritual apakah sangat relevan, relevan, cukup relevan atau tidak ada relevansi. Hasil tersebut dapat dilihat pada Tabel 8. 
Juvenil, 1(3), 310-324, (2020)

ekosistem laut terkait dengan pengaturan iklim, penyimpanan dan penyerapan karbon alami, pengendalian biologis serta penyerapan limbah); 3.Cultural services (jasa ekosistem laut yang dominan manfaat non materi yang diperoleh berupa nilai estetik, spiritual dan pemandangan indah): 4.Supporting services (jasa ekosistem laut dalam mendukung keberlanjutan jasa ekosistem lainnya).

Berdasarkan hasil penilaian penyedia jasa ekosistem yang dilakukan, bahwasannya pantai Siring Kemuning menunjukkan suplai ekosistem tertinggi yaitu tipe natural capital asset berupa laut, sedangkan natural capital asset terendah berupa pemukiman dapat dilihat pada (Tabel 8). Jasa-jasa ekosistem (Provisioning services) yang dimiliki berhubungan dengan kondisi sosial yang ada di wilayah pesisir pantai Siring Kemuning mata pencarian mereka bergerak dibidang perikanan yaitu nelayan. Bagi masyarakat pesisir, laut merupakan sumber daya yang digunakan dalam memenuhi kebutuhan hidup sehari hari.

\section{Permintaan (Demand) Jasa Ekosistem}

Permintaan jasa ekosistem merupakan jumlah dari semua barang dan jasa ekosistem saat ini yang digunakan pada daerah tertentu selama masa tertentu (Romadhon, 2013). Hasil penilaian terhadap permintaan jasa ekosistem yang ada di pantai Siring Kemuning didapat dengan melalui wawancara warga setempat dengan menanyakan Natural Capital Asset berhubungan dengan estetik, biodiversitas, budaya, ekonomi, keberlanjutan hidup, pembelajaran, rekreasi, dan spiritual apakah sangat relevan, relevan, cukup relevan atau tidak ada relevansi. Hasil tersebut dapat dilihat pada Tabel 9.

Tabel 9. Permintaan jasa ekosistem di pantai Siring Kemuning

\begin{tabular}{|c|c|c|c|c|c|c|c|c|c|c|c|}
\hline \multirow{2}{*}{\multicolumn{2}{|c|}{$\begin{array}{c}\text { Natural Capital } \\
\text { Asset }\end{array}$}} & \multicolumn{8}{|c|}{ Jasa Ekosistem Pantai Siring Kemuning } & \multirow[b]{2}{*}{0} & \multirow[b]{2}{*}{ Tidak ada relevansi } \\
\hline & & a & $\mathrm{b}$ & C & d & e & f & g & $\mathrm{h}$ & & \\
\hline 1 & $\begin{array}{l}\text { Kualitas } \\
\text { Perairan }\end{array}$ & 2 & 1 & 0 & 1 & 1 & 0 & 1 & 0 & 1 & Cukup relevan \\
\hline 2 & Tekstur Pantai & 1 & 0 & 0 & 1 & 1 & 0 & 2 & 0 & 2 & Relevan \\
\hline 3 & Pemukiman & 0 & 0 & 2 & 0 & 0 & 0 & 1 & 0 & 3 & Sangat relevan \\
\hline 4 & Tanah Terbuka & 1 & 0 & 0 & 0 & 0 & 0 & 2 & 0 & & \\
\hline 5 & Vegetasi & 1 & 1 & 0 & 0 & 0 & 0 & 0 & 0 & & \\
\hline 6 & Laut & 2 & 2 & 2 & 2 & 2 & 2 & 2 & 2 & & \\
\hline
\end{tabular}

\section{Keterangan}
a. Estetik
b. Biodiversity
c. Budaya
e. Keberlanjutan Hidup
f. Pembelajaran
d. Ekonomi
g. Rekreasi

Kesejahteraan masyarakat berhubungan erat dengan penyediaan jasa barang dan jasa dari ekosistem yang beragam. Permintaan hasil ekosistem disesuaikan dengan ruang atau tempat dan perubahan sumberdaya serta sosio ecological system (Romadhon, 2013). Permintaan hasil ekosistem oleh masyarakat di wilayah pesisir pantai Siring Kemuning menunjukkan permintaan jasa ekosistem terbesar berupa tipe natural capital asset laut, sedangkan terendah berupa tipe vegetasi dapat dilihat pada (Tabel 9).

Laut pada pesisir pantai Siring Kemuning merupakan sumber mata pencarian sebagian besar masyarakat pesisir tersebut sehingga permintaan jasa ekosistem pada tipe natural capital asset laut termasuk tinggi. Sedangkan tipe vegetasi merupakan yang terendah. Masyarakat disana membuat ayunan, gazebo dan tempat duduk santai untuk merealisasikan ekowisata pantai dapat dilihat pada Gambar 2.

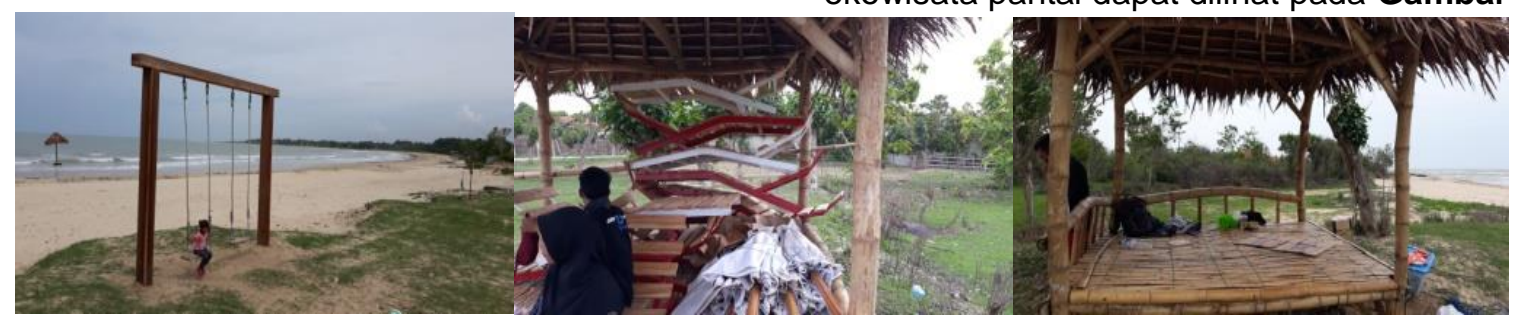

Gambar 2. Bangunan Wisata 
Pahlevi dan Romadhon, Penilaian Daya Dukung Kawasan Pantai

\begin{tabular}{llll}
\hline Status Ketersediaan & (Budget) Jasa & $\begin{array}{l}\text { hasil suplai jasa ekosistem di kurangi hasil dari } \\
\text { Ekosistem }\end{array}$ & $\begin{array}{l}\text { permintaan jasa ekosistem. Hasil dari } \\
\text { penilaian menggambarkan keseimbangan jasa }\end{array}$ \\
Penilaian status ketersediaan jasa ekosistem & $\begin{array}{l}\text { ekosistem yang ada di pantai Siring } \\
\text { dilakukan dengan membandingkan antara }\end{array}$ & $\begin{array}{l}\text { Kemuning. Adapun status ketersediaan jasa } \\
\text { ekosistem dapat dilihat pada Tabel 10 }\end{array}$
\end{tabular}

Tabel 10. Ketersediaan Jasa Ekosistem di Pantai Siring Kemuning

\begin{tabular}{|c|c|c|c|c|c|c|c|c|c|c|c|}
\hline \multirow{2}{*}{\multicolumn{2}{|c|}{$\begin{array}{c}\text { Natural Capital } \\
\text { Asset }\end{array}$}} & \multicolumn{8}{|c|}{ Jasa Ekosistem Pantai Siring Kemuning } & & \multirow[b]{3}{*}{$\begin{array}{l}\text { Penggunaan } \\
\text { melebihi kapasitas }\end{array}$} \\
\hline & & $a$ & $b$ & c & d & $\mathrm{e}$ & $f$ & $\mathrm{~g}$ & $\mathrm{~h}$ & & \\
\hline 1 & $\begin{array}{l}\text { Kualitas } \\
\text { Perairan }\end{array}$ & 1 & 2 & 0 & 1 & 1 & 0 & 2 & 0 & & \\
\hline 2 & Tekstur Pantai & 2 & 2 & 0 & 1 & 1 & 1 & 1 & 0 & -1 & \\
\hline 3 & Pemukiman & 0 & 0 & -1 & 0 & 0 & 1 & -1 & 0 & 0 & Keseimbangan \\
\hline 4 & Tanah Terbuka & 0 & 1 & 0 & 0 & 0 & 0 & -1 & 0 & 1 & \\
\hline 5 & Vegetasi & 0 & 0 & 0 & 1 & 1 & 1 & 1 & 0 & 2 & Kapasitas melebihi \\
\hline 6 & Laut & 1 & 1 & 0 & 1 & 1 & 1 & 1 & 1 & & Penggunaan \\
\hline
\end{tabular}
a. Estetik
b. Biodiversity
c. Budaya
e. Keberlanjutan Hidup
d. Ekonomi
f. Pembelajaran
g. Rekreasi
h. Spiritual

Status ketersediaan jasa ekosistem di pantai Siring Kemuning dalam permintaan jasa ekosistem masih dibawah suplai jasa ekosistem. Akan tetapi beberapa yang melebihi suplai jasa ekosistem. Status ketersediaan jasa ekosistem yang penggunaannya melebihi kapasitas yaitu pada tutupan pemukiman dan lahan terbuka. untuk pemukiman pada nilai budaya dan rekreasi serta tanah terbuka pada nilai rekreasi penggunaan masih melebihi kapasitas. Terpeliharanya natural capital asset dapat mendukung kehidupan manusia yang baik terhadap jasa dan barang. Sedangkan pada natural capital asset tanah terbuka pada nilai rekreasi yang melebihi kapasitas. Nilai yang melebihi kapasitas berpotensi menimbulkan kerusakan dan nantinya akan memberi dampak negatif bagi kehidupan manusia.

Status natural capital asset pada pantai Siring Kemuning masih tergolong terpelihara dengan baik sehingga memungkinkan untuk menyediakan barang dan jasa bagi kehidupan manusia. Nilai estetik terpelihara dibuktikan dengan pantai memiliki kualitas perairan, tekstur pantai, laut yang masih baik; nilai biodiversitas masih baik; nilai budaya masih tergolong baik namun pada pemukiman masih Tabel 11. Kesesuaian wisata pantai Siring Kemuning pada stasiun 1 (Surut)

\begin{tabular}{ccccccc}
\hline No & Parameter & $\begin{array}{c}\text { Batasan } \\
\text { Nilai }\end{array}$ & Nilai & $\begin{array}{c}\text { Skor } \\
(\mathrm{Si})\end{array}$ & $\begin{array}{c}\text { Bobot } \\
(\mathrm{Bi})\end{array}$ & $\begin{array}{c}\mathrm{n} \\
(\mathrm{Bi} \times \mathrm{Si})\end{array}$ \\
\hline 1 & Tipe Pantai & $\begin{array}{c}\text { Pasir } \\
\text { Putih }\end{array}$ & Pasir berbatu & 0 & 0,2 & 0 \\
\hline 2 & Lebar Pantai $(\mathrm{m})$ & $>15$ & $33,7-38$ & 3 & 0,2 & 0,6 \\
\hline 3 & Material dasar Perairan & Pasir & Pasir & 3 & 0,17 & 0,51
\end{tabular}

kurang; nilai ekonomi dan keberlanjutan hidup baik; pembelajaran baik karena masyarakat pesisir telah membuat kelompok sadar wisata (POKDAWIS); nilai rekreasi masih kurang pada pemukiman dan tanah terbuka karena kurangnya fasilitas untuk kamar mandi umum dan parkiran; dan nilai spiritual tergolong masih baik. Kondisi beberapa natural capital asset yang masih mampu menyediakan sejumlah jasa ekosistem dapat dijadikan sebagai daya tarik untuk ekowisata (Romadhon, 2013). Hal tersebut digunakan untuk mengontrol dan mengelola sejumlah aktivitas eksploitasi sumberdaya lainnya. Upaya dari pengolahan dan pengontrolan digunakan guna mempertahankan mutu kawasan tersebut tetap menarik wisatawan untuk berkunjung dan penduduk sekitar dalam mempertahankan hidup dengan memperoleh penghasilan dari pengunjung yang datang.

\section{Indeks Kesesuaian Wisata Pantai Siring Kemuning}

Adapun hasil dari penilaian kesesuaian wisata di pantai Siring Kemuning pada kondisi surut dan pasang dapat dilihat pada tabel berikut: sumberdaya, dan kualitas ekologi sehingga 
Juvenil, 1(3), 310-324, (2020)

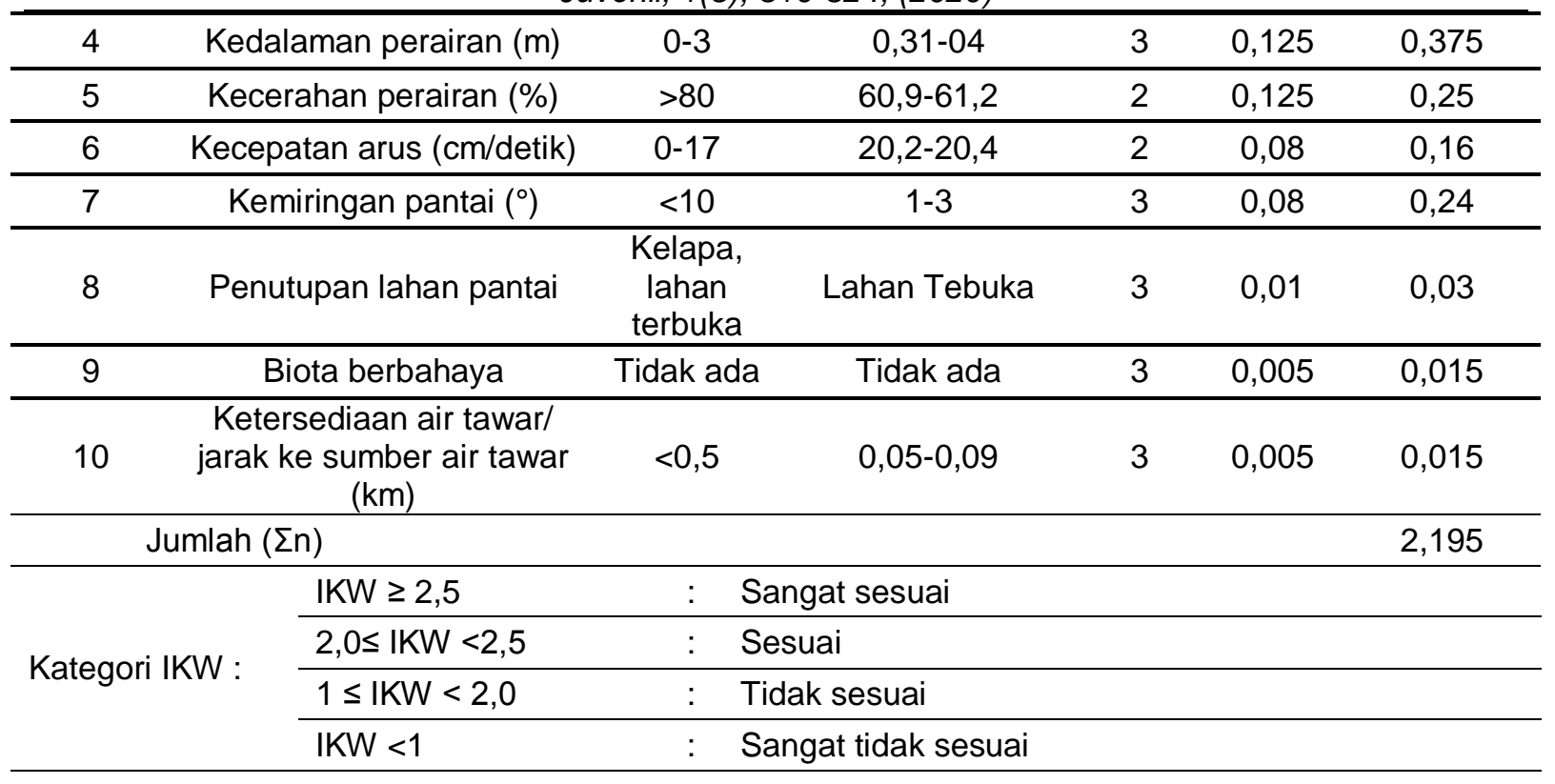

Tabel 12. Kesesuaian wisata pantai Siring Kemuning pada stasiun 1 (Pasang)

\begin{tabular}{|c|c|c|c|c|c|c|}
\hline No & Parameter & $\begin{array}{c}\text { Batasan } \\
\text { Nilai }\end{array}$ & Nilai & $\begin{array}{l}\text { Skor } \\
\text { (Si) }\end{array}$ & $\begin{array}{l}\text { Bobot } \\
\text { (Bi) }\end{array}$ & $\begin{array}{c}n \\
(\mathrm{Bi} \times \mathrm{Si})\end{array}$ \\
\hline 1 & Tipe Pantai & $\begin{array}{l}\text { Pasir } \\
\text { Putih }\end{array}$ & Pasir berbatu & 0 & 0,2 & 0 \\
\hline 2 & Lebar Pantai $(\mathrm{m})$ & $>15$ & $15,3-16,5$ & 3 & 0,2 & 0,6 \\
\hline 3 & Material dasar Perairan & Pasir & Pasir & 3 & 0,17 & 0,51 \\
\hline $\mathrm{Ke}$ & edalaman perairan $(\mathrm{m})$ & $0-3$ & $0,52-0,6$ & 3 & 0,125 & 0,375 \\
\hline $\mathrm{Ke}$ & ecerahan perairan (\%) & $>80$ & $54,1-57,9$ & 2 & 0,125 & 0,25 \\
\hline No & Parameter & $\begin{array}{c}\text { Batasan } \\
\text { Nilai }\end{array}$ & Nilai & $\begin{array}{l}\text { Skor } \\
(\mathrm{Si})\end{array}$ & $\begin{array}{l}\text { Bobot } \\
\text { (Bi) }\end{array}$ & $\begin{array}{c}\mathrm{n} \\
(\mathrm{Bi} \times \mathrm{Si}) \\
\end{array}$ \\
\hline $\mathrm{Kec}$ & cepatan arus (cm/detik) & $0-17$ & $21,1-21,2$ & 2 & 0,08 & 0,16 \\
\hline 7 & Kemiringan pantai $\left({ }^{\circ}\right)$ & $<10$ & $1-3$ & 3 & 0,08 & 0,24 \\
\hline 8 & Penutupan Iahan pantai & $\begin{array}{l}\text { Kelapa, } \\
\text { lahan } \\
\text { terbuka }\end{array}$ & Lahan Terbuka & 3 & 0,01 & 0,03 \\
\hline 9 & Biota berbahaya & Tidak ada & Tidak Ada & 3 & 0,005 & 0,015 \\
\hline $\begin{array}{r}\mathrm{Ke} \epsilon \\
\text { jara }\end{array}$ & $\begin{array}{l}\text { etersediaan air tawar/ } \\
\text { rak ke sumber air tawar } \\
(\mathrm{km})\end{array}$ & $<0,5$ & $0,05-0,09$ & 3 & 0,005 & 0,015 \\
\hline \multicolumn{4}{|c|}{ Jumlah $(\Sigma n)$} & & & 2,195 \\
\hline \multirow{4}{*}{ Kategori IKW : } & $\mathrm{IKW} \geq 2,5$ & \multicolumn{2}{|c|}{ Sangat sesuai } & & & \\
\hline & $2,0 \leq \mathrm{IKW}<2,5$ & \multicolumn{2}{|c|}{ Sesuai } & & & \\
\hline & $1 \leq \mathrm{IKW}<2,0$ & \multicolumn{2}{|c|}{ Tidak sesuai } & & & \\
\hline & $\mathrm{IKW}<1$ & \multicolumn{2}{|c|}{ Sangat tidak sesuai } & & & \\
\hline
\end{tabular}

Tabel 13. Kesesuaian wisata pantai Siring Kemuning pada stasiun 2 (Surut)

\begin{tabular}{ccccccc}
\hline No & Parameter & $\begin{array}{c}\text { Batasan } \\
\text { Nilai }\end{array}$ & Nilai & $\begin{array}{c}\text { Skor } \\
(\mathrm{Si})\end{array}$ & $\begin{array}{c}\text { Bobot } \\
(\mathrm{Bi})\end{array}$ & $\begin{array}{c}\mathrm{n} \\
(\mathrm{Bix} \\
\mathrm{Si})\end{array}$ \\
\hline 1 & Tipe Pantai & $\begin{array}{c}\text { Pasir } \\
\text { Putih }\end{array}$ & Pasir putih campur pecahan karang & 2 & 0,2 & 0,4 \\
\hline 2 & Lebar Pantai $(\mathrm{m})$ & $>15$ & $32-43$ & 3 & 0,2 & 0,6
\end{tabular}


Pahlevi dan Romadhon, Penilaian Daya Dukung Kawasan Pantai

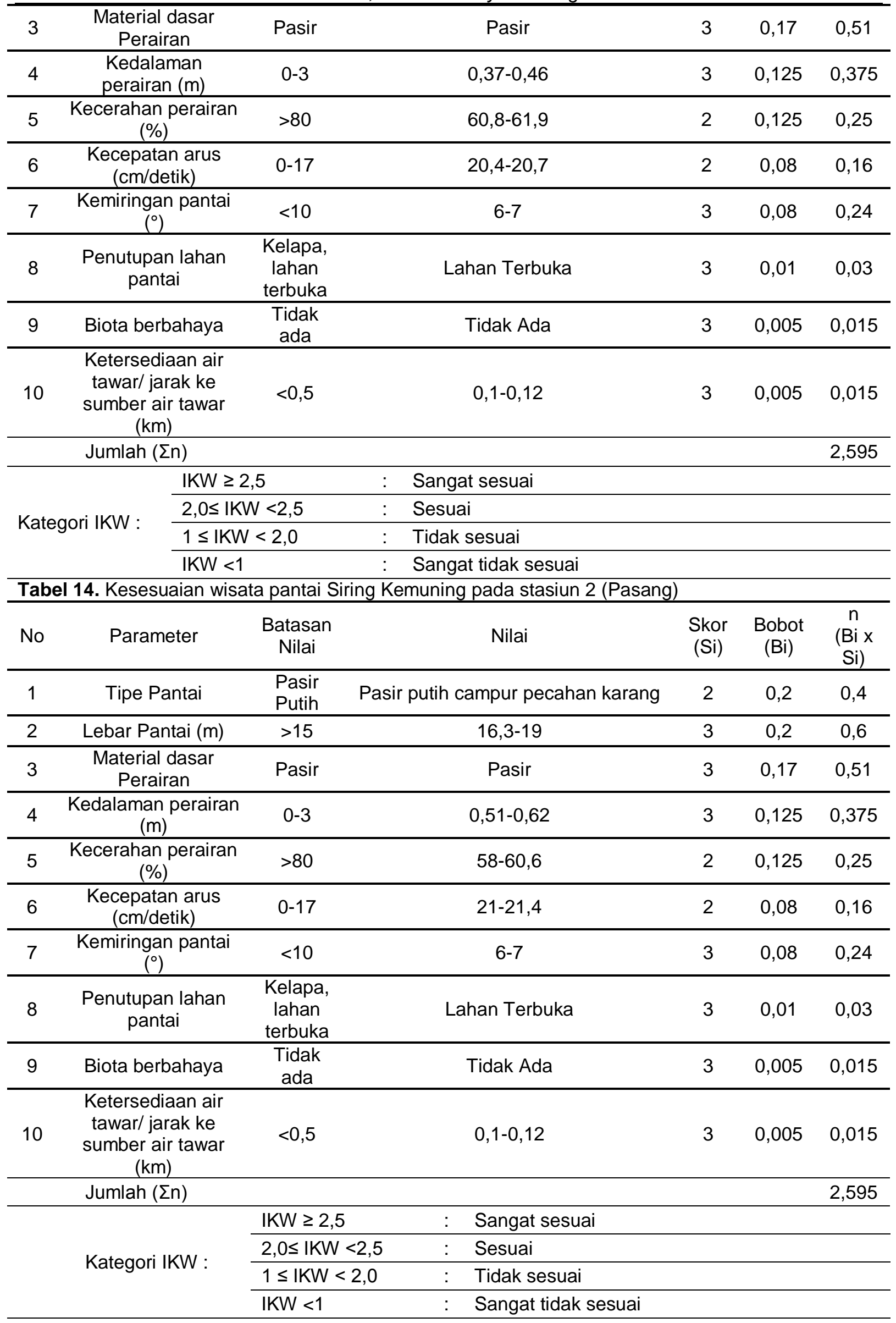


Juvenil, 1(3), 310-324, (2020)

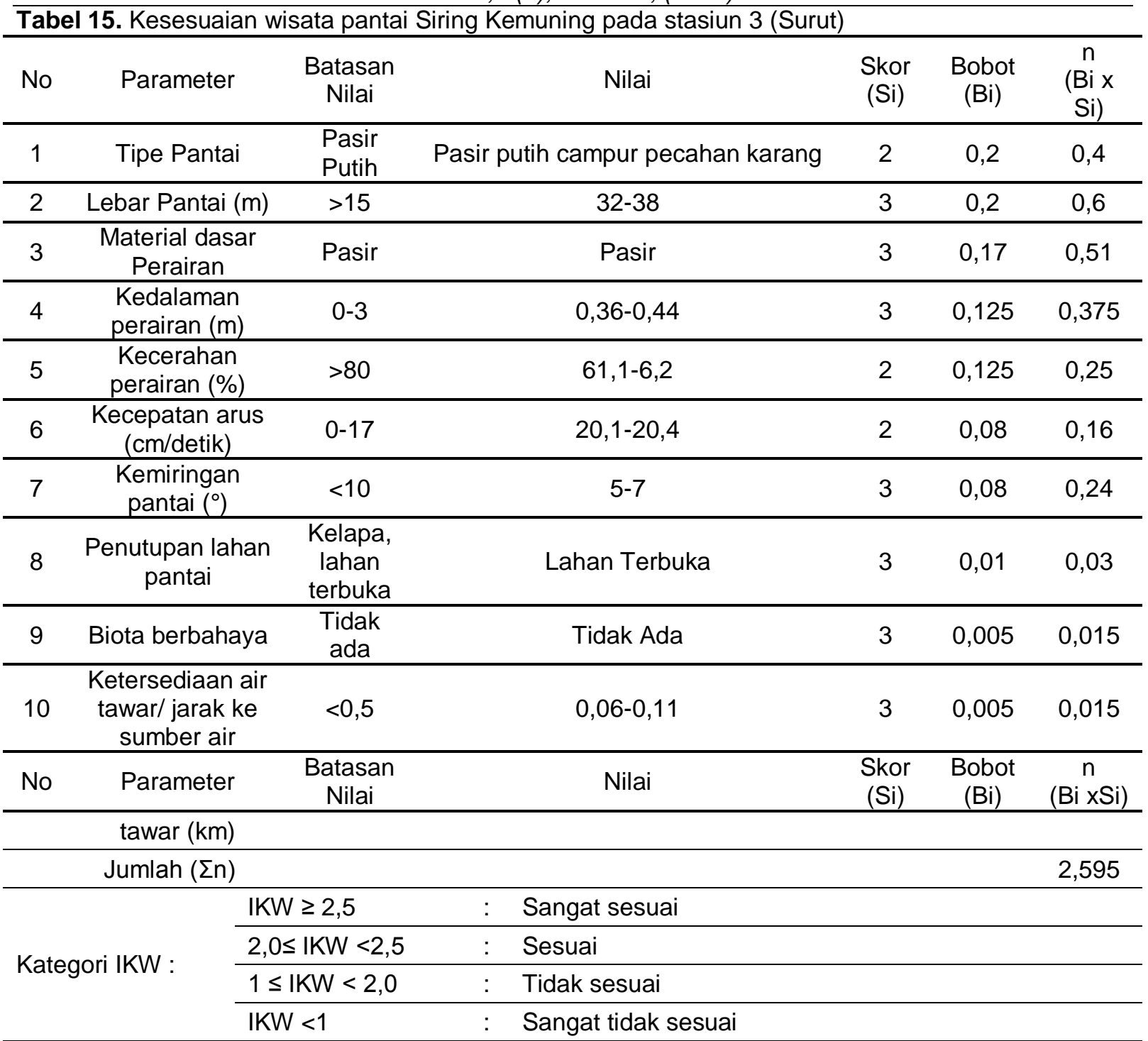

Tabel 15. Kesesuaian wisata pantai Siring Kemuning pada stasiun 3 (Pasang)

\begin{tabular}{|c|c|c|c|c|c|c|}
\hline No & Parameter & $\begin{array}{l}\text { Batasan } \\
\text { Nilai }\end{array}$ & Nilai & $\begin{array}{l}\text { Skor } \\
\text { (Si) }\end{array}$ & $\begin{array}{c}\text { Bobot } \\
(\mathrm{Bi})\end{array}$ & $\begin{array}{c}\mathrm{n} \\
(\mathrm{Bi} x \\
\mathrm{Si}) \\
\end{array}$ \\
\hline 1 & Tipe Pantai & $\begin{array}{l}\text { Pasir } \\
\text { Putih }\end{array}$ & Pasir putih campur pecahan karang & 2 & 0,2 & 0,4 \\
\hline 2 & Lebar Pantai (m) & $>15$ & $15,8-18,3$ & 3 & 0,2 & 0,6 \\
\hline 3 & $\begin{array}{c}\text { Material dasar } \\
\text { Perairan }\end{array}$ & Pasir & Pasir & 3 & 0,17 & 0,51 \\
\hline 4 & $\begin{array}{l}\text { Kedalaman } \\
\text { perairan }(\mathrm{m})\end{array}$ & $0-3$ & $0,57-0,67$ & 3 & 0,125 & 0,375 \\
\hline 5 & $\begin{array}{l}\text { Kecerahan } \\
\text { perairan (\%) }\end{array}$ & $>80$ & $56-57,4$ & 2 & 0,125 & 0,25 \\
\hline 6 & $\begin{array}{c}\text { Kecepatan arus } \\
\text { (cm/detik) }\end{array}$ & $0-17$ & $21-21,2$ & 2 & 0,08 & 0,16 \\
\hline 7 & $\begin{array}{c}\text { Kemiringan } \\
\text { pantai }\left(^{\circ}\right)\end{array}$ & $<10$ & $5-7$ & 3 & 0,08 & 0,24 \\
\hline 8 & $\begin{array}{c}\text { Penutupan lahan } \\
\text { pantai }\end{array}$ & $\begin{array}{c}\text { Kelapa, } \\
\text { lahan } \\
\text { terbuka }\end{array}$ & Lahan Terbuka & 3 & 0,01 & 0,03 \\
\hline 9 & Biota berbahaya & $\begin{array}{l}\text { Tidak } \\
\text { ada }\end{array}$ & Tidak Ada & 3 & 0,005 & 0,015 \\
\hline
\end{tabular}


Pahlevi dan Romadhon, Penilaian Daya Dukung Kawasan Pantai

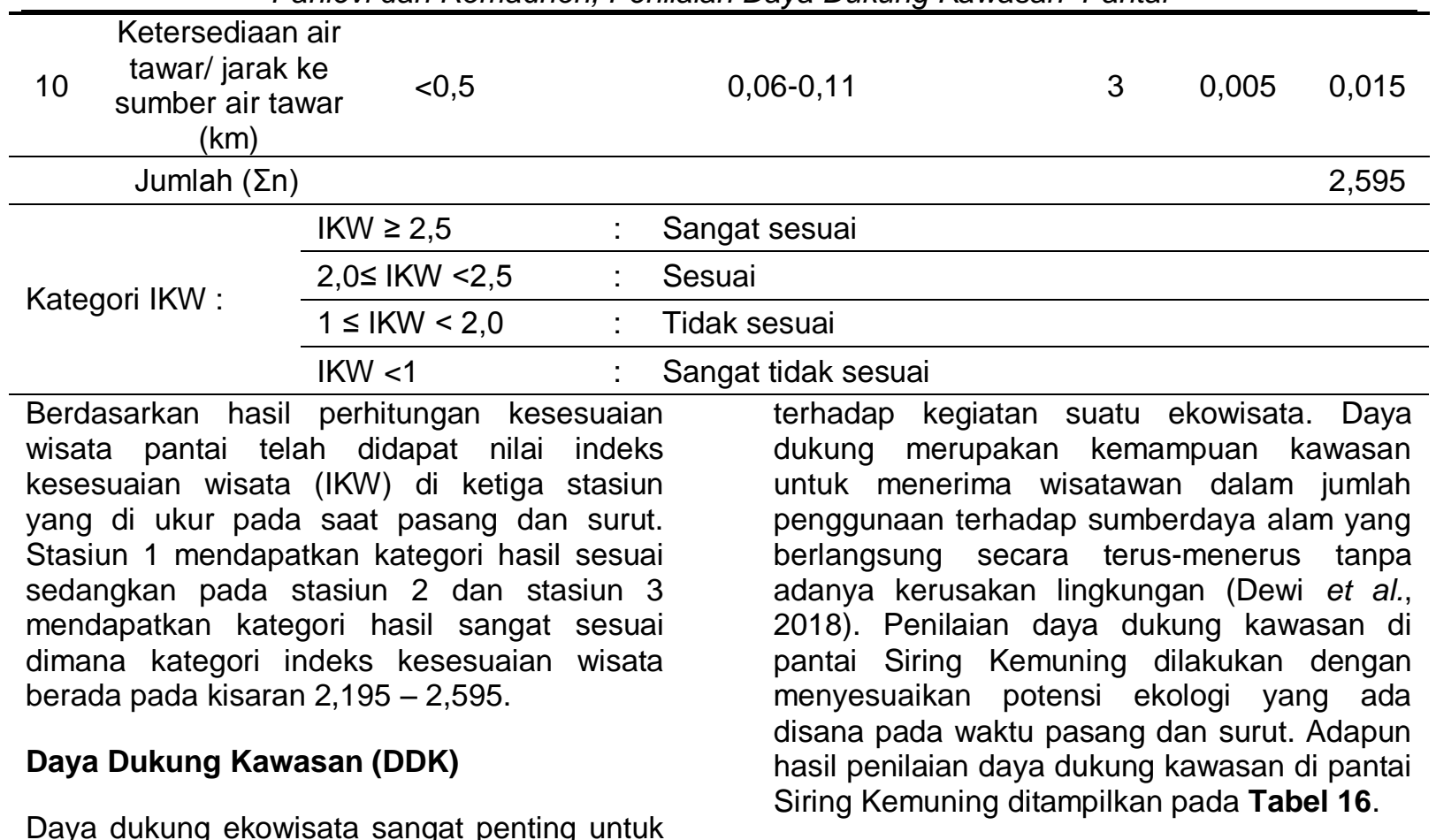
menjaga suatu kawasan secara berkelanjutan

Tabel 16. Daya Dukung Kawasan Pantai Siring Kemuning saat Surut dan Pasang

\begin{tabular}{|c|c|c|c|c|c|c|c|}
\hline $\begin{array}{c}\text { Jenis } \\
\text { Kegiatan } \\
\text { Ekowisata }\end{array}$ & Stasiun & $\begin{array}{c}\mathrm{K} \\
\text { ( } \text { pengunjung) }\end{array}$ & $\begin{array}{c}\mathrm{Lt} \\
\text { (Unit } \\
\text { Area) }\end{array}$ & $\begin{array}{l}\text { Lp (Luas } \\
\text { Area) }\end{array}$ & $\begin{array}{l}\text { Wp (Waktu } \\
\text { yang } \\
\text { dibutuhkan) }\end{array}$ & $\begin{array}{c}\text { Wt } \\
\text { (Total } \\
\text { Waktu) }\end{array}$ & DDK \\
\hline \multirow{6}{*}{$\begin{array}{l}\text { Wisata } \\
\text { Pantai }\end{array}$} & \multirow[b]{2}{*}{1} & \multirow[b]{2}{*}{1} & $25 \mathrm{~m}^{2}$ & $\begin{array}{l}\text { Surut } \\
6845 \mathrm{~m}^{2}\end{array}$ & 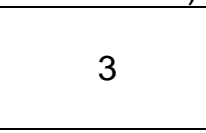 & 6 & $\begin{array}{l}548 \\
\text { orang } \\
\text { / hari }\end{array}$ \\
\hline & & & $25 \mathrm{~m}^{2}$ & $\begin{array}{l}\text { Pasang } \\
854 \mathrm{~m}^{2}\end{array}$ & 3 & 6 & $\begin{array}{l}68 \\
\text { orang } \\
\text { / hari }\end{array}$ \\
\hline & \multirow{2}{*}{2} & \multirow{2}{*}{1} & \multirow{2}{*}{$25 \mathrm{~m}^{2}$} & $\begin{array}{c}\text { Surut } \\
10503 \\
\mathrm{~m}^{2} \\
\end{array}$ & \multirow{2}{*}{3} & \multirow{2}{*}{6} & $\begin{array}{c}840 \\
\text { orang } \\
\text { / hari }\end{array}$ \\
\hline & & & & $\begin{array}{l}\text { Pasang } \\
1439 \mathrm{~m}^{2}\end{array}$ & & & $\begin{array}{l}115 \\
\text { orang } \\
\text { / hari }\end{array}$ \\
\hline & \multirow{2}{*}{3} & \multirow[t]{2}{*}{1} & \multirow{2}{*}{$25 \mathrm{~m}^{2}$} & $\begin{array}{c}\text { Surut } \\
11290 \\
\mathrm{~m}^{2} \\
\end{array}$ & \multirow{2}{*}{3} & \multirow{2}{*}{6} & $\begin{array}{l}903 \\
\text { orang } \\
\text { / hari }\end{array}$ \\
\hline & & & & $\begin{array}{l}\text { Pasang } \\
1415 \mathrm{~m}^{2}\end{array}$ & & & $\begin{array}{l}113 \\
\text { orang } \\
\text { / hari }\end{array}$ \\
\hline \multicolumn{4}{|c|}{$\begin{array}{l}\text { Berdasarkan hasil penilaian daya dukung } \\
\text { kawasan pantai Siring Kemuning memiliki } \\
\text { daya dukung yang berbeda-beda tiap } \\
\text { stasiunnya, karena pada setiap stasiun } \\
\text { berbeda-beda luasan areanya hal tersebut } \\
\text { dipengaruhi oleh pasang surut. Untuk } \\
\text { menampung wisatawan pada stasiun } 1 \text { ketika } \\
\text { surut sebanyak } 548 \text { orang/hari dan saat } \\
\text { pasang sebanyak } 68 \text { orang/hari. Daya dukung }\end{array}$} & \multicolumn{4}{|c|}{$\begin{array}{l}\text { kawasan pada stasiun } 2 \text { ketika surut dapat } \\
\text { menampung wisatawan saat surut sebanyak } \\
840 \text { orang/hari dan ketika pasang sebanyak } \\
115 \text { orang/hari. Sedangkan pada stasiun } 3 \\
\text { daya dukung kawasan yang dapat } \\
\text { menampung wisatawan saat kondisi surut } \\
\text { sebanyak } 903 \text { orang/hari dan ketika pasang } \\
\text { sebanyak } 113 \text { orang/hari. Menurut (Nugraha e } \\
\text { al., 2013) perhitungan daya dukung kawasan }\end{array}$} \\
\hline
\end{tabular}


Juvenil, 1(3), 310-324, (2020)

digunakan untuk mencegah kerusakan dari suatu sumberdaya alam dan lingkungan sehingga keberadaan, fungsi dan kelestariannya tetap terjaga dan masyarakat atau pengguna sumberdaya alam tersebut tidak dirugikan. Upaya daya dukung kawasan dilakukan agar tidak terjadi pemanfaatan yang berlebihan dan hal tersebut merupakan usaha pencegahan kerusakan ekosistem sejak dini.

\section{Kesimpulan}

\section{KESIMPULAN DAN SARAN}

Berdasarkan hasil penelitian yang telah dilakukan, dapat disimpulkan bahwa Pantai Siring Kemuning memiliki status mutu perairan yang baik. Keterkaitan status ketersediaan jasa ekosistem di pantai Siring Kemuning untuk pengembangan wisata masih mampu menyediakan sejumlah jasa ekosistem untuk daya tarik ekowisata. Pantai Siring Kemuning mempunyai kesesuaian untuk pengembangan wisata pantai kategori sangat sesuai dan sesuai ( IKW 2,195 - 2,595). Daya dukung untuk wisata pantai Siring Kemuning untuk kegiatan wisata pantai sebesar 548 orang/ hari saat surut dan 68 orang/ hari saat pasang pada stasiun 1, pada Stasiun 2 sebesar 840 orang/ hari saat surut dan 115 orang/ hari saat pasang, dan pada stasiun 3 sebesar 903 orang/ hari saat surut dan 113 orang/ hari saat pasang.

\section{Saran}

Saran untuk penelitian lanjutan adalah membandingkan penelitian pantai Siring Kemuning dengan pantai lainnya (pantai selatan atau pantai utara) yang lokasinya berjauhan

\section{DAFTAR PUSTAKA}

Akhmad, D. S., Koesoemadji, K., \& Pratikto, I. (2014). Kesesuaian Lahan Sebagai Ekowisata Bahari Di Pantai Tanjung Natuna. Journal of Marine Research, 3(4), 420-428.

Dewi, K. P., Anggoro, S., \& Rudiyanti, S. (2018). Kesesuaian Perairan Dan Daya Dukung Lingkungan Tanjung Gelam Untuk Wisata Rekreasi Pantai Di Taman Nasional Karimunjawa. Management of Aquatic Resources Journal, 7(4), 361369.

Ermawan R. W. (2008). Kajian Sumberdaya Pantai Untuk Kesesuaian Ekowisata di Pantai Prigi, Kabupaten Trenggalek,
Provinsi Jawa Timur. Skripsi. Institut Pertanian Bogor. Bogor.

Hamuna, B., Tanjung, R. H., \& MAury, H. (2018). Kajian Kualitas Air Laut dan Indeks Pencemaran Berdasarkan Parameter Fisika-Kimia di Perairan Distrik Depapre, Jayapura. Jurnal IImu Lingkungan, 16(1), 35-43

Indra, N., Sari, S., Rahayu, G., Oktaviandra, R., Handoko, A., Putri, V. S., \& Hanapi, M. I. (2019). Kualitas Lingkungan dan Kesesuaian Wisata Pesisir Kawasan Carocok Painan, Kabupaten Pesisir Selatan. Jurnal Kapita Selekta Geografi, 2(5), 43-51.

Johan, Y. (2017). Kajian Potensi Ekowisata Padang Lamun Di Perairan Pantai Basing Dusun Limas Pulau Sebangka Kecamatan Senayang Kabupaten Lingga. Skripsi. Universitas Maritim Raja Ali Haji. Tanjungpinang.

Keputusan Menteri Lingkungan Hidup Republik Indonesia. (2004). Keputusan Menteri Negara Lingkungan Hidup Nomor 51/MENLH/51/2004 Tentang Baku Mutu Air Laut Untuk Wisata Bahari.

Lucyanti S., B. Hendrarto., M. Izzati. (2013). Penilaian Daya Dukung Wisata di Objek Wisata Bumi Perkemahan Palutungan Taman Nasional Gunung Ciremai Propinsi Jawa Barat. Prosiding Seminar Nasional Pengelolaan Sumberdaya Alam dan Lingkungan. Universitas Diponegoro : $232-230$.

Noor M. A. F. F. (2019). Analisis Kesesuaian Dan Daya Dukung Lingkungan Pulau Gili Noko Bawean Sebagai Kawasan Ekowisata Pantai. Skripsi. Universitas Trunojoyo Madura. Madura.

Nugraha, H. P., Indarjo, A., \& Helmi, M. (2013). Studi kesesuaian dan daya dukung kawasan untuk rekreasi pantai di Pantai Panjang Kota Bengkulu. Journal of Marine Research, 2(2), 130139.

Patty, S. I. (2013). Distribusi suhu, salinitas dan oksigen terlarut di Perairan Kema, Sulawesi Utara. Jurnal IImiah Planax, 1(3).

Ramadhan S., P. Patana., Z. A. Harahap. (2014). Analisis Kesesuaian dan Daya Dukung Kawasan Wisata Pantai Cermin Kabupaten Serdang Begadai. Aquacoastmarine, 5(4), 31-43.

Romadhon, A. (2013). Optimasi Pemanfaatan Pulau-Pulau Kecil Berbasis Daya Dukung Bagi Peruntukan Wisata (Kasus Gugus Pulau Sapeken, Kecamatan 
Sapeken, Kabupaten Sumenep). Disertasi. Institut Pertanian Bogor. Bogor

Sari, T. E. Y. (2012). Studi Parameter Fisika dan Kimia Daerah Penangkapan Ikan Perairan Selat Asam Kabupaten Kepulauan Meranti Propinsi Riau. Jurnal Perikanan dan Kelautan, 17(01), 88-100.

Sukandar, S., Dewi, C. S., \& Handayani, M. (2017). Analisis kesesuaian dan daya dukung lingkungan untuk pengembangan wisata bahari di Pulau Bawean Kabupaten Gresik Provinsi Jaya Timur. DEPIK Jurnal IImu-IImu Perairan, Pesisir dan Perikanan, 6(3), 205-213.

Syamsi Achmad Badarus. 2016. Analisa Potensi Pariwisata di Bangkalan yang Sesuai dengan Syariah dalam Menunjang Jawa Timur sebagai Salah Satu Destinasi Pariwisata Syariah. Prosiding Seminar Nasional \& Call For Papers. Universitas Trunojoyo Madura : 38-49.

Tambunan Jimmy Margomgom., Sutrisno Anggoro., Hartuti Purnaweni. 2013. Kajian Kualitas Lingkungan dan Kesesuaian Wisata Pantai Tanjung Pesona Kabupaten Bangka. Prosiding Seminar Nasional Pengelolaan sumberdaya Alam dan Lingkungan. Universitas Diponegoro : 356-362.

Telaumbanua, B. V., Efizon, D., \& Windarti, W. (2017). Kajian Pengembangan Dan Pengelolaan Potensi Ekowisata Bahari Di Kecamatan Tuhemberua Kabupaten Nias Utara Provinsi Sumatera Utara. Berkala Perikanan Terubuk, 45(2), 8595.

Yulianda F. (2019). Ekowisata Perairan: Suatu Konsep Kesesuaian dan Daya Dukung Wisata Bahari dan Wisata Air Tawar. Bogor: PT Penerbit IPB Press.

Yulisa, E. N., Johan, Y., \& Hartono, D. (2016). Analisis kesesuaian dan daya dukung ekowisata pantai kategori rekreasi pantai Laguna Desa Merpas Kabupaten Kaur. Jurnal Enggano, 1(1), 97-111. 